\title{
MODEL RANTAI MARKOV PANGSA PASAR OPERATOR SELULAR DI UNIVERSITAS BINA NUSANTARA, JAKARTA BARAT
}

\author{
Tjia Fie Tjoe $^{1}$; Haryadi Sarjono ${ }^{2}$
}

\begin{abstract}
Article presented the replacement of cellular cards operator service user, especially for GSM of five operators that are dominant in Indonesia, those are $X L$, Mentari, Simpati, AS, and IM3 for six months with teenagers sample of 295 students from Management Department of Bina Nusantara University. The used method was Markov analysis. Besides that, it also used State and Probability State that were used to identify the whole possible situation of a process or system. Based on the research, from 295 samples of teenagers, it can be seen that there is a switching from one provider into another.
\end{abstract}

Keywords: Markov chain model, market share, operator, cellular

\section{ABSTRAK}

Artikel bertujuan untuk mengetahui perpindahan kartu pengguna jasa operator selular khusus GSM untuk 5 jenis operator yang paling dominan di Indonesia, yaitu XL, Mentari, Simpati, AS, dan IM3 selama selang waktu 6 bulan dengan jumlah sampel kalangan remaja, yaitu 295 mahasiswa Jurusan Manajemen Universitas Bina Nusantara. Metode yang digunakan adalah Markov. Selain itu, juga digunakan State dan Probabilitas State untuk mengidentifikasi seluruh kondisi yang mungkin dari suatu proses atau sistem. Berdasarkan penelitian, dari jumlah sampel sebanyak 295 yang diambil dari kalangan remaja, terlihat adanya perpindahan dari provider yang satu ke provider yang lain.

Kata kunci: model rantai Markov, pangsa pasar, operator, selular

\footnotetext{
1, 2 Jurusan Manajemen, Fakultas Ekonomi, Universitas Bina Nusantara, JI. K.H. Syahdan No. 9, Palmerah, Jakarta Barat 11480, fieChu@binus.edu, haryadi_s@binus.edu
} 


\section{PENDAHULUAN}

Memasuki era globalisasi ini, teknologi pun telah merambat secara luas ke bidang komunikasi. Munculnya telepon pada tahun silam menjadi pemacu kreativitas teknologi untuk terus menghadirkan teknologi baru di bidang komunikasi. Namun seperti yang telah diketahui, pesawat telepon yang umumnya terpasang di tiap rumah memiliki kendala utama, yaitu penggunaannya yang tidak fleksibel, dalam arti hanya dapat digunakan di lokasi pemasangannya saja.

Hadirnya telepon seluler (handphone) memberikan gaya hidup baru bagi masyarakat, terutama dalam berkomunikasi. Masyarakat merasakan betul manfaat yang mereka peroleh dari penggunaan telepon seluler ini. Mereka menilai biaya yang dikeluarkan untuk penggunaan telepon seluler adalah sebanding dengan nilai yang diberikannya. Hal itu terbukti dari permintaan atas telepon seluler yang meningkat secara signifikan dalam beberapa tahun belakangan ini. Pada bulan Maret 2007, hasil survei menunjukkan pengguna telepon seluler di Indonesia telah mencapai angka 75 juta orang.

Operator GSM di Indonesia saat ini memiliki jumlah paling besar. Setidaknya terdapat 5 jenis operator GSM yang dominan di Indonesia, yaitu XL, Mentari, Simpati, AS, dan IM3. Bahkan, jumlah ini dirasa akan semakin bertambah terus mengingat permintaan dalam industri ini mengalami peningkatan yang sangat signifikan. Sebagai contoh, munculnya pesaing baru, yaitu Three (3). Ketatnya persaingan membuat setiap operator terus mencari dan mempertahankan keunggulan kompetitifnya sehingga mereka tidak kehilangan pangsa pasarnya dan sesekali mampu merebut pangsa pasar yang lebih besar.

Industri itu ditandai dengan kekuatan tawar pelanggan yang amat tinggi. Rendahnya switching cost membuat para pelanggan sangat mudah untuk berpindah dari satu operator GSM ke operator GSM lainnya. Hal itu memaksa setiap operator di satu sisi harus berupaya keras untuk terus mempertahankan para pelanggannya dan di sisi lain harus mampu merebut hati para pelanggan barunya. Pemasaran, promosi, layanan, serta keunggulan kualitas produk, baik dari segi harga maupun fitur, menjadi kunci kesuksesan dalam bertahan di industri ini. Keadaan tersebut membuat setiap operator sulit untuk mengetahui pangsa pasar masing-masing. Ditambah lagi perpindahan operator yang dilakukan pelanggan akan menambah kerumitan dalam pengukuran. Untuk itu, dilakukan pangsa pasar menggunakan teknik Markov sehingga dapat memperoleh perkiraan pangsa pasar dari kelima operator GSM di Indonesia.

Berikut adalah identifikasi masalah penelitian ini: Bagaimana penggantian kartu GSM di kalangan mahasiswa Universitas Bina Nusantara? Bagaimana pangsa pasar yang dimiliki oleh lima operator GSM dominan di Indonesia? Bagaimana besarnya pangsa pasar yang dimiliki oleh lima operator GSM dominan di Indonesia pada kondisi ekuilibrium? 


\section{TINJAUAN PUSTAKA}

\section{Teori Markov}

Markov merupakan sebuah teknik yang berhubungan dengan probabilitas akan state di masa mendatang dengan menganalisis probabilitas saat ini (Render, Barry et. al., 2006:652). Teknik itu memiliki beragam aplikasi dalam dunia bisnis, diantaranya pangsa pasar, prediksi kerugian, prediksi penerimaan mahasiswa baru di universitas, dan menentukan apakah sebuah mesin akan mengalami kerusakan di masa mendatang. Definisi lain menyatakan bahwa Analisis Markov merupakan sebuah metode dalam menganalisis perilaku saat ini dari beberapa variabel dengan tujuan untuk memprediksi perilaku dari variabel yang sama di masa mendatang (Isaacson, et al., 1976:802).

Prosedur ini dikembangkan oleh seorang ahli matematika Rusia bernama Andrei A. Markov yang menggunakan metode ini untuk mendeskripsikan dan memprediksi perilaku dari partikel gas di dalam sebuah wadah tertutup. Markov membuat asumsi bahwa sistem dimulai pada state atau kondisi awal. Misalnya, dua buah perusahaan yang saling bersaing masing-masing memiliki pangsa pasar sebesar $40 \%$ dan $60 \%$ sebagai state awal. Mungkin saja dalam dua bulan pangsa pasar untuk kedua perusahaan tersebut mengalami perubahan menjadi $45 \%$ dan $55 \%$. Untuk memprediksi state ini, melibatkan pemahaman akan kecenderungan atau probabilitas dari perubahan satu state ke state berikutnya. Untuk masalah tertentu, probabilitas ini dapat dikumpulkan dan diletakkan dalam suatu matriks atau tabel. Matriks perubahan probabilitas ini menunjukkan kecendrungan bahwa suatu sistem akan berubah dalam suatu suatu periode ke periode berikutnya.

\section{State dan Probabilitas State}

State digunakan untuk mengidentifikasi seluruh kondisi yang mungkin dari suatu proses atau sistem (Render, Barry et. al., 2006:652). Misalnya saja, sebuah mesin dapat berada dalam satu state dari dua state yang ada dalam satu waktu. Mesin tersebut dapat berfungsi dengan baik atau dapat juga berfungsi secara tidak baik (rusak). Kondisi ketika mesin dapat berfungsi disebut dengan state pertama sedangkan kondisi ketika mesin tidak dapat berfungsi disebut dengan state kedua. Contoh lainnya adalah mahasiswa manajemen di Universitas Bina Nusantara dapat memilih satu diantara peminatan yang ada, yaitu peminatan e-Business, Marketing, dan Entrepreneurship. Masing-masing peminatan itu dapat dianggap sebagai sebuah state.

Menurut Render et. al. (2006:652), $\backslash$ dalam Markov, diasumsikan bahwa state memiliki dua buah sifat, yaitu Collectively exhaustive dan Mutually exclusive. Collectively exhaustive - peneliti dapat membuat daftar seluruh state yang mungkin timbul atau dimiliki oleh suatu sistem atau proses dan asumsinya adalah terdapat jumlah state yang terbatas untuk sistem. Mutually exclusive - sebuah sistem hanya dapat berada 
dalam satu state dalam satu waktu (sistem tidak dapat berada dalam lebih dari satu state). Misalnya, mahasiswa manajemen UBinus hanya dapat memilih satu peminatan dari tiga peminatan yang ada.

\section{Probabilitas State}

Setelah state dari sistem atau proses yang akan diteliti telah diidentifikasi, langkah selanjutnya adalah menentukan probabilitas sistem berada dalam state tertentu menggunakan vektor probabilitas state.

dan

$$
\begin{aligned}
\pi(i) & =\text { vektor dari probabilitas state untuk periode } i \\
& =\left(\pi_{1}, \pi_{2}, \pi_{3}, \ldots, \pi_{\mathrm{n}}\right)
\end{aligned}
$$

$$
\begin{aligned}
\mathrm{n} & =\text { jumlah state } \\
\pi_{1}, \pi_{2}, \pi_{3}, \ldots, \pi_{\mathrm{n}} & =\text { probabilitas berada dalam state ke- } 1, \text { state ke- } 2, \text { state ke-n }
\end{aligned}
$$

Untuk beberapa kasus yang hanya terdapat satu item, misalnya sebuah mesin, dapat ditentukan dengan pasti state dari item tersebut. Misalnya, jika penelitian dilakukan hanya pada satu buah mesin maka dapat diketahui dengan pasti bahwa pada saat ini mesin dapat berfungsi dengan baik atau tidak berfungsi. Vektor untuk mesin tersebut dapat diggambarkan sebagai berikut.

dan

$$
\pi(1)=(1,0)
$$

$$
\begin{aligned}
& \pi_{1}=1=\text { probabilitas berada dalam state } \mathrm{ke}-1 \\
& \pi_{2}=0=\text { probabilitas berada dalam state } \mathrm{ke}-2
\end{aligned}
$$

Hal itu menunjukkan bahwa probabilitas mesin berfungsi dengan baik, state ke-1, adalah 1 dan probabilitas mesin tidak berfungsi, state ke-2, adalah 0 untuk periode pertama. Namun dalam beberapa kasus, penelitian dilakukan tidak hanya pada satu item saja melainkan beberapa item. Contoh lain, penelitian dilakukan di suatu kota yang memiliki tiga buah toko bahan makanan (Render et. al., 2006:653-656). Terdapat total 100.000 orang yang berbelanja di ketiga toko bahan makanan tersebut pada bulan tertentu. Terdapat 40.000 orang yang berbelanja di American Food Store, dinamakan dengan state 1 . Terdapat 30.000 orang yang berbelanja di Food Mart, dinamakan dengan state 2. Terdapat 30.000 orang yang berbelanja di Atlas Foods, dinamakan dengan state 3 . Probabilitas dari satu orang yang berbelanja pasa satu diantara tiga toko bahan makanan tersebut, yaitu:

$$
\begin{array}{lr}
\text { State } 1 \text { - American Food Store } & 40.000 / 100.000=0.40=40 \% \\
\text { State } 2 \text { - Food Mart } & 30.000 / 100.000=0.30=30 \% \\
\text { State } 3 \text { - Atlas Foods } & 30.000 / 100.000=0.30=30 \%
\end{array}
$$


Jika probabilitas tersebut diletakkan dalam vektor probabilitas state maka akan menjadi:

dan

$$
\pi(1)=(0.4,0.3,0.3)
$$

$\pi(1)=$ vektor probabilitas state ketiga toko bahan makanan untuk periode 1

$\pi_{1}=0.4=$ probabilitas satu orang yang akan berbelanja di American Food Store, state 1

$\pi_{2}=0.3=$ probabilitas satu orang yang akan berbelanja di Food Mart, state 2

$\pi_{3}=0.3=$ probabilitas satu orang yang akan berbelanja di Atlas Foods, state 3

Probabilitas yang ditunjukkan oleh vektor tersebut menggambarkan pangsa pasar untuk ketiga toko bahan makanan untuk periode pertama dan American Food Store memiliki pangsa pasar sebesar $40 \%$, Food Mart memiliki pangsa pasar sebesar $30 \%$, Atlas Food memiliki pangsa pasar sebesar 30\%. Tentunya pangsa pasar itu memiliki kondisi yang tidak stabil, yaitu tiap toko dapat mengalami perubahan pangsa pasar untuk periode berikutnya. Pihak manajemen tentunya ingin mengetahui bagaimana pangsa pasar mereka mengalami perubahan seiring berjalannya waktu. Pelanggan tidak selalu tetap berbelanja di toko tertentu tetapi dapat saja berpindah ke toko lain untuk melakukan pembelian selanjutnya.

Penelitian untuk ketiga toko bahan makanan menetapkan bahwa $80 \%$ pelanggan American Food Store pada periode pertama akan kembali untuk berbelanja di toko itu pada periode berikutnya. 10\% pelanggan American Food Store berpindah ke Food Mart dan sisanya sebesar $10 \%$ berpindah ke Atlas Food. Untuk pelanggan yang berbelanja di Food Mart, 70\% pelanggan akan kembali, 10\% berpindah ke American Food Store, dan $20 \%$ berpindah ke Atlas Food. Untuk pelanggan yang berbelanja di Atlas Food, 60\% pelanggan akan kembali, 20\% berpindah ke American Food Store, dan 20\% berpindah ke Food Mart. Gambar 1 memperlihatkan diagram pohon untuk menggambarkan situasi ini.

Perhatikan bahwa dari $40 \%$ pangsa pasar American Food Store untuk periode pertama, $32 \%(0.4 \times 0.8=0.32)$ akan kembali, $4 \%$ akan berpindah ke Food Mart, dan 4\% akan berpindah ke Atlas Food. Untuk menghitung pangsa pasar American Food Store pada periode berikutnya, tambahkan nilai $32 \%$ yang berasal dari pelanggan yang kembali dengan nilai 3\% yang berasal dari pelanggan Food Mart yang berpindah ke American Food Store dan nilai 6\% yang berasal dari pelanggan Atlas Food yang berpindah ke American Food Store sehingga American Food Store akan memiliki 41\% pangsa pasar pada periode berikutnya. 


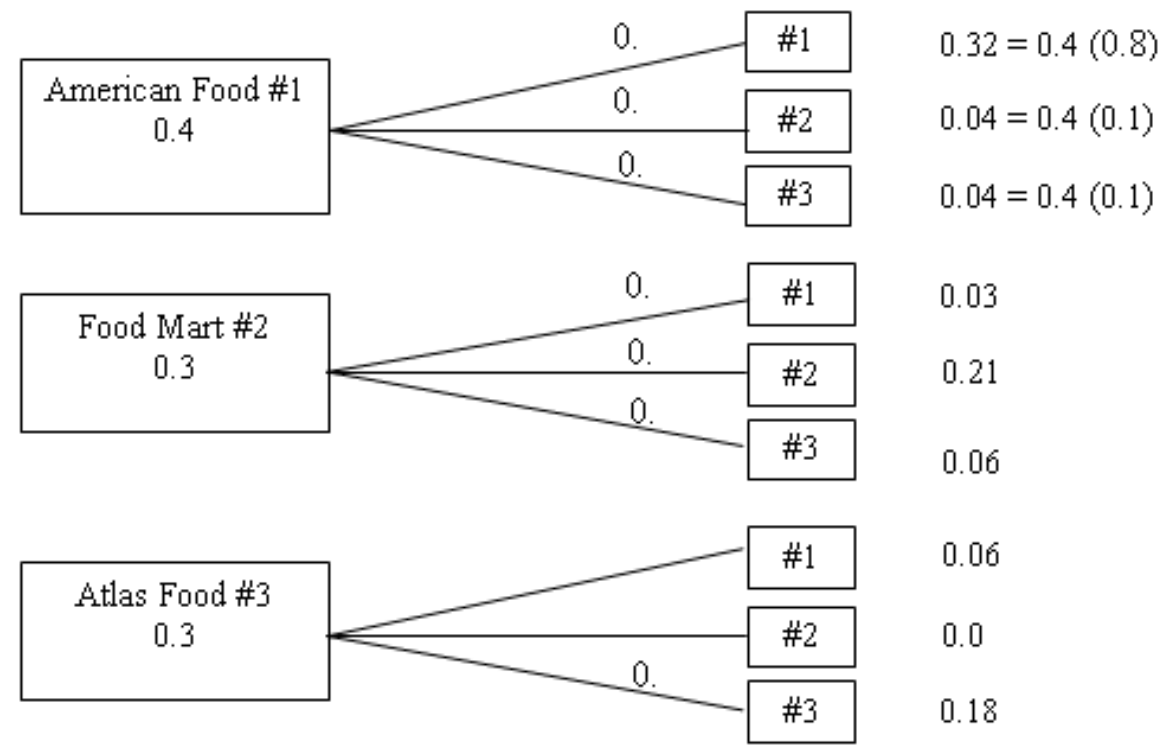

Sumber: Render, 2006:654

\section{Gambar 1 Contoh Diagram Pohon}

Dibandingkan dengan diagram pohon, penggunaan matriks probabilitas state lebih memudahkan dalam melakukan perhitungan. Matriks itu digunakan bersama dengan probabilitas state saat ini untuk memprediksi kondisi di masa mendatang

\section{Matriks Transisi Probabilitas}

Matriks Transisi Probabilitas memungkinkan untuk melakukan perhitungan probabilitas state di masa mendatang berdasarkan pada state saat ini.

$\mathrm{Pij}=$ probabilitas kondisi berada dalam state $\mathrm{j}$ di masa mendatang berdasarkan pada state i saat ini.

Misalkan $\mathrm{P}_{12}$ adalah probabilitas berada pada state 2 di masa mendatang dan sebelumnya berada pada state 1 .

$\mathrm{P}=$ matriks transisi probabilitas

$$
P=\left(\begin{array}{ccccc}
P_{11} & P_{12} & P_{13} & \ldots & P_{1 n} \\
P_{21} & P_{22} & P_{28} & \ldots . & P_{2 n} \\
\cdot & & & & \cdot \\
\cdot & & & & \cdot \\
P_{m 1} & \ldots & & P_{m n}
\end{array}\right)
$$


Nilai Pij biasanya ditentukan secara empiris. Misalkan, penelitian menunjukkan bahwa $10 \%$ orang yang saat ini berbelanja pada toko ke-1 (state 1) pada periode berikutnya akan berbelanja di toko ke-2 (state 2), maka $\mathrm{P}_{12}=0.1$ atau $10 \%$. Berdasarkan contoh soal sebelumnya mengenai tiga toko bahan makanan, selanjutnya akan dibuat matriks transisi probabilitas untuk menentukan berapa persentase pelanggan akan berpindah tiap periodenya. Matriksnya adalah sebagai berikut.

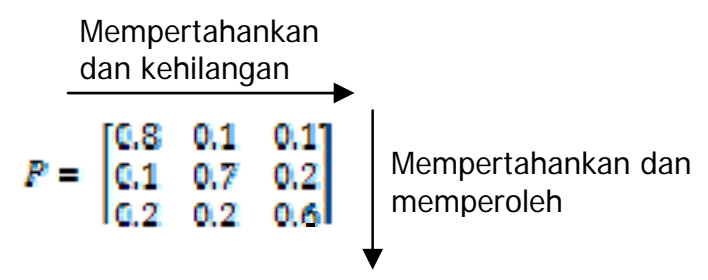

Toko American Food mewakili state 1, Food Mart state 2, dan Atlas Food state 3. Arti probabilitas tersebut dapat digambarkan seperti berikut.

Baris 1

$0.8=\mathrm{P}_{11}=$ probabilitas berada pada state 1 setelah sebelumnya berada pada state 1

$0.1=\mathrm{P}_{12}=$ probabilitas berada pada state 2 setelah sebelumnya berada pada state 1

$0.1=\mathrm{P}_{13}=$ probabilitas berada pada state 3 setelah sebelumnya berada pada state 1 Baris 2

$0.1=\mathrm{P}_{21}=$ probabilitas berada pada state 1 setelah sebelumnya berada pada state 2

$0.7=\mathrm{P}_{22}=$ probabilitas berada pada state 2 setelah sebelumnya berada pada state 2

$0.2=\mathrm{P}_{23}=$ probabilitas berada pada state 3 setelah sebelumnya berada pada state 2 Baris 3

$0.2=\mathrm{P}_{31}=$ probabilitas berada pada state 1 setelah sebelumnya berada pada state 3

$0.2=\mathrm{P}_{31}=$ probabilitas berada pada state 2 setelah sebelumnya berada pada state 3

$0.6=\mathrm{P}_{31}=$ probabilitas berada pada state 3 setelah sebelumnya berada pada state 3

\section{Memprediksi Kondisi di Masa Mendatang}

Menurut Render, et. al. (2006:656), salah satu tujuan Markov adalah memprediksi masa depan. Berdasarkan contoh kasus sebelumnya, yaitu probabilitas sama dengan pangsa pasar, maka dimungkinkan untuk menghitung pangsa pasar di masa mendatang untuk American Food Store, Food Mart, dan Atlas Food. Jika periode saat ini adalah 0 , menghitung probabilitas state untuk periode berikutnya (periode 1) dapat dilakukan sebagai berikut.

$$
\pi(1)=\pi(0) \mathrm{P}
$$

Jika penghitungan dilakukan pada periode $\mathrm{n}$ maka probabilitas state untuk periode $\mathrm{n}+1$ adalah sebagai berikut.

$$
\pi(\mathrm{n}+1)=\pi(\mathrm{n}) \mathrm{P}
$$


Persamaan tersebut dapat digunakan untuk menjawab pertanyaan atas pangsa pasar di masa mendatang untuk ketiga toko bahan makanan. Perhitungannya sebagai berikut.

$$
\begin{aligned}
\pi(1)= & \pi(0) \mathrm{P} \\
= & (0.4,0.3,0.3) \quad\left[\begin{array}{lll}
0.8 & 0.1 & 0.1 \\
0.1 & 0.7 & 0.2 \\
0.2 & 0.2 & 0.6
\end{array}\right] \\
= & {[(0.4)(0.8)+(0.3)(0.1)+(0.3)(0,2),(0.4)(0.1)(0.3)(0.7)+(0.3)(0.2),} \\
& (0.4)(0.1)+(0.3)(0.2)+(0.3)(0.6)] \\
= & (0.41,0.31,0.28)
\end{aligned}
$$

\section{Kondisi Ekuilibrium}

Pada masa awal, kehilangan maupun memperoleh pelanggan merupakan hal yang lazim terjadi. Namun, lama-kelamaan kehilangan dan perolehan pelanggan akan menjadi semakin kecil. Merupakan sebuah kondisi yang sangat masuk akal jika di masa mendatang akan tercapai suatu kondisi yang stabil, yaitu semua state yang ada tidak mengalami perubahan lagi atau disebut juga dengan kondisi ekuilibrium. Kondisi itu akan tercapai hanya jika tidak ada state yang melakukan tindakan yang dapat mengubah matriks transisi probabilitas. Berdasarkan pada kasus toko bahan makanan yang dibahas sebelumnya maka kita dapat mengetahui pada saat kondisi pasar stabil maka berapakah pangsa pasar dari masing-masing toko bahan makanan tersebut.

\section{Ekuilibrium Satu Toko}

Untuk mengilustrasikan ekuilibrium ini, diasumsikan terdapat sebuah matriks transisi probabilitas yang baru

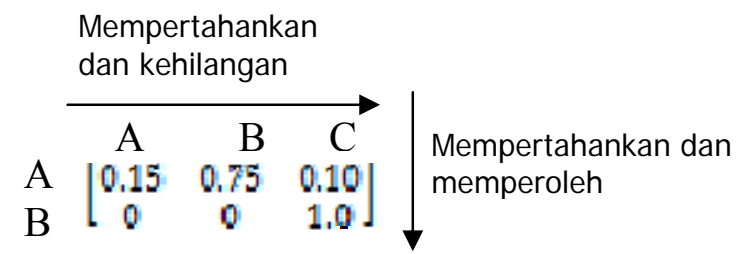

Karena C tidak pernah kehilangan pelanggannya dan karena kedua toko kehilangan pelanggannya beralih ke toko $\mathrm{C}$ maka hanya tinggal menunggu waktu saja hingga toko $\mathrm{C}$ akan meraih seluruh pelanggan yang ada. Kondisi seperti itu dikenal dengan istilah sink atau basin dari suatu state yang berarti salah satu toko yaitu C akhirnya akan meraih seluruh pelanggan. $\mathrm{C}$ juga disebut sebagai absorbing state. 


\section{Ekuilibrium Dua Toko}

Ekuilibrium jenis kedua diilustrasikan melalui sebuah matriks transisi probabilitas yang baru seperti berikut ini.

Mempertahankan

dan kehilangan

A B C

$\mathrm{A}$
$\mathrm{B}$
$\mathrm{C}$$\left[\begin{array}{ccc}0.90 & 0.05 & 0.05 \\ 0 & 0.50 & 0.50 \\ 0 & 0.50 & 0.50\end{array}\right] \downarrow \begin{aligned} & \text { Mempertahankan dan } \\ & \text { memperoleh }\end{aligned}$

Dari matriks tersebut, terlihat bahwa toko B dan $\mathrm{C}$ pada akhirnya akan merebut seluruh pelanggan toko A. Hal itu terjadi karena A kehilangan 0.05 pelanggannya beralih ke toko $\mathrm{B}$ dan 0.05 pelanggannya beralih ke toko $\mathrm{C}$ dan tidak memperoleh pelanggan baru baik dari toko B maupun C. kondisi ekuilibrium pasar hanya dialami oleh toko B dan C. Kedua toko tersebut harus berbagi pelanggan yang ada di pasar.

\section{Ekuilibrium Tiga Toko}

Ekuilibrium jenis ketiga, yaitu ketika tidak terjadi sink atau basin. Berdasarkan contoh kasus toko bahan makanan sebelumnya, akan dicari kondisi ekuilibrium pangsa pasar ketiga toko bahan makanan tersebut.

Mempertahankan

dan kehilangan

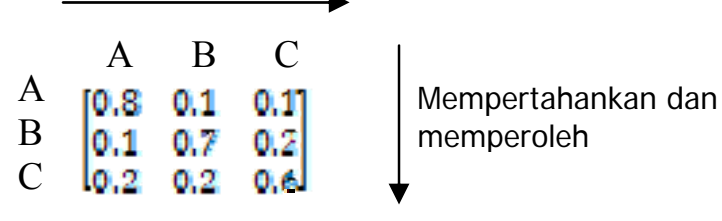

Berdasarkan matriks tersebut, dapat dibentuk sebuah persamaan dan pangsa pasar A merupakan jumlah dari pangsa pasar A + pangsa pasar A yang berasal B + pangsa pasar A yang berasal C. Hal yang sama juga dapat diterapkan untuk pangsa pasar B dan C sehingga jika dituliskan dalam bentuk persamaan matematika akan menjadi seperti berikut.

$$
\begin{aligned}
& \mathrm{A}=0.8 \mathrm{~A}+0.1 \mathrm{~B}+0.2 \mathrm{C}(1) \\
& \mathrm{B}=0.1 \mathrm{~A}+0.7 \mathrm{~B}+0.2 \mathrm{C}(2) \\
& \mathrm{C}=0.1 \mathrm{~A}+0.2 \mathrm{~B}+0.6 \mathrm{C}(3)
\end{aligned}
$$


Karena jumlah probabilitas pangsa pasar ketiga toko tersebut sama dengan 1 maka dapat ditambahkan persamaan:

$$
1=\mathrm{A}+\mathrm{B}+\mathrm{C}
$$

Pada persamaan (1) hingga (3) terdapat tanda persamaan yang sama sehingga persamaan tersebut dapat diubah menjadi:

$$
\begin{aligned}
& 0=-0.2 \mathrm{~A}+0.1 \mathrm{~B}+0.2 \mathrm{C} \\
& 0=0.1 \mathrm{~A}-0.3 \mathrm{~B}+0.2 \mathrm{C} \\
& 0=0.1 \mathrm{~A}+0.2 \mathrm{~B}-0.4 \mathrm{C} \\
& 1=\mathrm{A}+\mathrm{B}+\mathrm{C}
\end{aligned}
$$

Karena terdapat 4 persamaan dan hanya 3 yang tidak diketahui, dapat dihilangkan salah satu dari tiga persamaan yang ada (hilangkan persamaan 3) dan memecahkan tiga persamaan lainnya untuk mencari pangsa pasar ekuilibrium.

$$
\begin{aligned}
& \begin{array}{c|c|l}
0=-0.2 \mathrm{~A}+0.1 \mathrm{~B}+0.2 \mathrm{C} & \mathrm{x} 3 & 0=-0.6 \mathrm{~A}+0.3 \mathrm{~B}+0.6 \mathrm{C} \\
0=0.1 \mathrm{~A}-0.3 \mathrm{~B}+0.2 \mathrm{C} & \mathrm{x} 1 & 0=0.1 \mathrm{~A}-0.3 \mathrm{~B}+0.2 \mathrm{C}
\end{array}+ \\
& 0.8 \mathrm{C}=0.5 \mathrm{~A} \\
& \mathrm{C}=0.625 \mathrm{~A} \\
& 0=-0.2 \mathrm{~A}+0.1 \mathrm{~B}+0.2 \mathrm{C} \quad \mathrm{x} 1 \mid 0=-0.2 \mathrm{~A}+0.1 \mathrm{~B}+0.2 \mathrm{C} \\
& 0=0.1 \mathrm{~A}-0.3 \mathrm{~B}+0.2 \mathrm{C} \quad \mathrm{x} 1 \mid 0=\underline{0.1 \mathrm{~A}-0.3 \mathrm{~B}+0.2 \mathrm{C}} \\
& 0=-0.3 \mathrm{~A}+0.4 \mathrm{~B} \\
& 0.4 \mathrm{~B}=0.3 \mathrm{~A} \\
& \mathrm{~B}=0.75 \mathrm{~A}
\end{aligned}
$$

Setelah mendapatkan nilai $\mathrm{B}$ dan $\mathrm{C}$, dapat mencari nilai $\mathrm{A}$ dengan memasukkannya ke dalam persamaan berikut.

$$
\begin{aligned}
& 1=\mathrm{A}+\mathrm{B}+\mathrm{C} \\
& 1=\mathrm{A}+0.75 \mathrm{~A}+0.625 \mathrm{~A} \\
& 1=2.375 \mathrm{~A} \\
& \mathrm{~A}=0.421052631 \approx 0.421
\end{aligned}
$$

Langkah terakhir adalah mencari nilai dari $\mathrm{B}$ dan $\mathrm{C}$, yaitu:

$$
\begin{aligned}
& \mathrm{B}=0.75 \mathrm{~A}=0.75(0.421) \quad=0.31575 \approx 0.316 \\
& \mathrm{C}=0.625 \mathrm{~A}=0.625(0.421)=0.263125 \approx 0.263
\end{aligned}
$$

Pada kondisi ekuilibrium, pangsa pasar untuk toko $\mathrm{A}=0.421$ (42.1\%), $\mathrm{B}=0.75$ (75\%), $\mathrm{C}=0.263$ (26.3\%). Untuk membuktikan kondisi ekuilibrium ini, dapat dilakukan perhitungan nilai pangsa pasar ekuilibrium dengan matriks transisi probabilitas. 


\section{METODE PENELITIAN}

\section{Desain Penelitian}

Tabel 1 Desain Penelitian

\begin{tabular}{ccclc}
\hline $\begin{array}{c}\text { Tujuan } \\
\text { Penelitian }\end{array}$ & $\begin{array}{c}\text { Jenis } \\
\text { Penelitian }\end{array}$ & $\begin{array}{c}\text { Metode } \\
\text { Penelitian }\end{array}$ & \multicolumn{1}{c}{ Unit Analisis } & Horizon Waktu \\
\hline$($ T-1 $)$ & Deskriptif & Survei & $\begin{array}{l}\text { Individu } \rightarrow \text { mahasiswa Universitas } \\
\text { Bina Nusantara } \\
\text { Individu } \rightarrow \text { mahasiswa Universitas } \\
\text { Bina Nusantara }\end{array}$ & Longitudinal \\
(T-2) & Deskriptif & Survei & Longitudinal \\
(T-3) & Deskriptif & Survei & $\begin{array}{l}\text { Individu } \rightarrow \text { mahasiswa Universitas } \\
\text { Bina Nusantara } \\
\text { Individu } \rightarrow \text { mahasiswa Universitas } \\
\text { Bina Nusantara }\end{array}$ & One Shoot - Cross Section \\
& Deskriptif & Survei - Cross Section & \\
\hline
\end{tabular}

Sumber: Hasil Pengolahan Data, 2007

(T-1) Menduga pangsa pasar yang dimiliki oleh lima operator GSM dominan di Indonesia pada periode berikutnya.

(T-2) Mengetahui besarnya pangsa pasar yang dimiliki oleh lima operator GSM dominan di Indonesia pada kondisi ekuilibrium.

(T-3) Mengetahui sumber referensi pemilihan operator GSM.

(T-4) Mengetahui penilaian konsumen terhadap operator GSM.

\section{Operasionalisasi Variabel Penelitian}

Tabel 2 Operasionalisasi Variabel

\begin{tabular}{llll}
\hline \multicolumn{1}{c}{ Variabel/Sub Variabel } & Konsep Variabel/Sub Variabel & \multicolumn{1}{c}{ Indikator } & Skala Pengukur \\
\hline $\begin{array}{l}\text { Pangsa pasar } \\
\text { operator GSM dominan } \\
\text { Indonesia dalam dua periode. }\end{array}$ & $\begin{array}{l}\text { Jumlah pengguna atas satu } \\
\text { operator dibandingkan dengan } \\
\text { seluruh pengguna operator }\end{array}$ & $\begin{array}{l}\text { Kepemilikan atas } \\
\text { operator GSM pada } \\
\text { periode pertama } \\
\text { Kepemilikan atas } \\
\text { operator GSM pada } \\
\text { periode kedua }\end{array}$ & Nominal \\
\hline $\begin{array}{l}\text { Referensi konsumen dalam } \\
\text { pemilihan operator GSM. }\end{array}$ & $\begin{array}{l}\text { Referensi yang diperoleh } \\
\text { konsumen dalam memilih operator } \\
\text { yang digunakannya. }\end{array}$ & $\begin{array}{l}\text { Sumber referensi } \\
\text { konsumen }\end{array}$ & Nominal \\
& & &
\end{tabular}




\begin{tabular}{|c|c|c|c|}
\hline $\begin{array}{c}\text { Variabel/Sub } \\
\text { Variabel }\end{array}$ & Konsep Variabel/Sub Variabel & Indikator & $\begin{array}{c}\text { Skala } \\
\text { Pengukur }\end{array}$ \\
\hline $\begin{array}{l}\text { Penilaian } \\
\text { konsumen terhadap } \\
\text { operator GSM. }\end{array}$ & $\begin{array}{l}\text { Penilaian yang diberikan oleh } \\
\text { konsumen atas operator GSM } \\
\text { yang mereka gunakan. }\end{array}$ & $\begin{array}{ll}\text { - } & \text { Tarif Bicara } \\
\text { - } & \text { Tarif SMS } \\
\text { - } & \text { Sinyal } \\
\text { - } & \text { Jangkauan Area } \\
\text { - } & \text { Harga Perdana } \\
\text { - } & \text { Harga Voucher } \\
\text { - } & \text { Layanan } \\
\text { - } & \text { Promo } \\
\text { - } & \text { Fitur }\end{array}$ & Interval \\
\hline
\end{tabular}

Sumber: Hasil Pengolahan Data, 2007

\section{PEMBAHASAN}

\section{Data Provider Seluler}

Penelitian yang dilakukan adalah meneliti bagaimanakah pangsa pasar provider seluler GSM yang ada di Indonesia dengan jumlah sampel sebanyak 296 mahasiswa aktif (kalangan remaja) dari berbagai jurusan di BINUS University. Provider seluler GSM yang diteliti, yaitu AS, IM3, Mentari, Simpati, dan XL. Penelitian pada periode pertama menunjukkan bahwa terdapat 15 orang yang menggunakan provider AS, dinamakan dengan state 1 . Terdapat 41 orang yang menggunakan provider IM3, dinamakan dengan state 2 . Terdapat 29 orang yang menggunakan provider Mentari, dinamakan dengan state 3. Terdapat 64 orang yang menggunakan provider Simpati, dinamakan dengan state 4 . Terdapat 146 orang yang menggunakan provider XL, dinamakan dengan state 5 . Probabilitas dari satu orang yang menggunakan satu diantara kelima provider seluler GSM tersebut:

State $1-$ AS

$$
\begin{array}{ll}
\text { State } 1-\text { AS } & 15 / 295=0.05=5 \% \\
\text { State 2 - IM3 } & 41 / 295=0.14=14 \% \\
\text { State 3 - Mentari } & 29 / 295=0.10=10 \% \\
\text { State 4 - Simpati } & 64 / 295=0.22=22 \%
\end{array}
$$$$
\text { State } 5-\text { XL } \quad 146 / 295=0.49=49 \%
$$
menjadi:

Jika probabilitas tersebut diletakkan dalam vektor probabilitas state maka akan

dan:

$$
\pi(1)=(0.05,0.14,0.10,0.22,0.49)
$$

$\pi(1)=$ vektor probabilitas state ketiga toko bahan makanan untuk periode 1

$\pi_{1}=0.05=$ probabilitas satu orang yang menggunakan provider AS, state 1

$\pi_{2}=0.14=$ probabilitas satu orang yang menggunakan provider IM3, state 2

$\pi_{3}=0.10=$ probabilitas satu orang yang menggunakan provider Mentari, state 3

$\pi_{4}=0.22=$ probabilitas satu orang yang menggunakan provider Simpati, state 4

$\pi_{5}=0.49=$ probabilitas satu orang yang menggunakan provider XL, state 5 
Penelitian pada periode kedua menunjukkan adanya perpindahan dari provider yang satu ke provider yang lain. Sebesar $54 \%$ dari pengguna AS tetap menggunakan provider AS, 13\% dari pengguna AS berpindah ke provider IM3, 7\% dari pengguna AS berpindah ke provider Mentari, 13\% dari pengguna AS berpindah ke provider Simpati, $13 \%$ dari pengguna AS berpindah ke provider XL. Untuk pelanggan yang menggunakan provider IM3, sebesar 59\% dari pengguna IM3 tetap menggunakan provider IM3, 2\% dari pengguna IM3 berpindah ke provider AS, 12\% dari pengguna IM3 berpindah ke provider Mentari, 10\% dari pengguna IM3 berpindah ke provider Simpati, 17\% dari pengguna IM3 berpindah ke provider XL. Untuk pelanggan yang menggunakan provider Mentari, sebesar 72\% dari pengguna Mentari tetap menggunakan provider Mentari, $4 \%$ dari pengguna Mentari berpindah ke provider AS, 7\% dari pengguna Mentari berpindah ke provider IM3, 7\% dari pengguna Mentari berpindah ke provider Simpati, 10\% dari pengguna Mentari berpindah ke provider XL.

Untuk pelanggan yang menggunakan provider Simpati, sebesar 58\% dari pengguna Simpati tetap menggunakan provider Simpati, 5\% dari pengguna Simpati berpindah ke provider AS, 14\% dari pengguna Simpati berpindah ke provider IM3, 9\% dari pengguna Simpati berpindah ke provider Mentari, 14\% dari pengguna Simpati berpindah ke provider XL. Untuk pelanggan yang menggunakan provider XL, sebesar $80 \%$ dari pengguna XL tetap menggunakan provider XL, $1 \%$ dari pengguna XL berpindah ke provider AS, 5\% dari pengguna XL berpindah ke provider IM3, 10\% dari pengguna XL berpindah ke provider Mentari, 4\% dari pengguna XL berpindah ke provider Simpati.

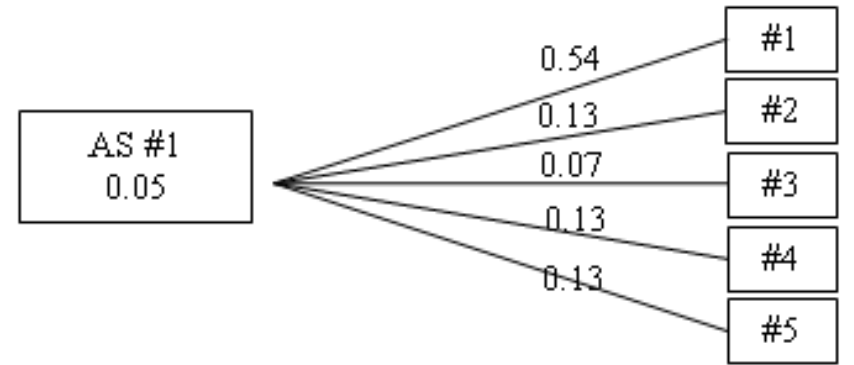

$0.027=0.05(0.54)$

$0.0065=0.05(0.13)$

$0.0035=0.05(0.07)$

$0.0065=0.05(0.13)$

$0.0065=0.05(0.13)$

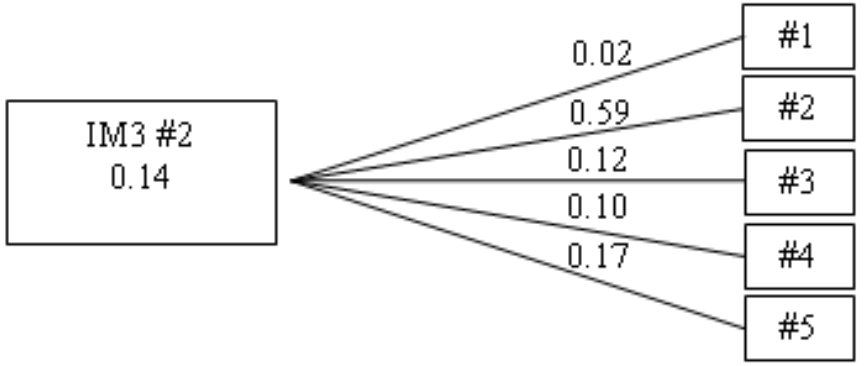

$0.0028=0.14(0.02)$

$0.0826=0.14(0.59)$

$0.00168=0.14(0.12)$

$0.014=0.14(0.10)$

$0.0238=0.14(0.17)$

Model Rantai Markov... (Tjia Fie Tjoe; Haryadi Sarjono) 


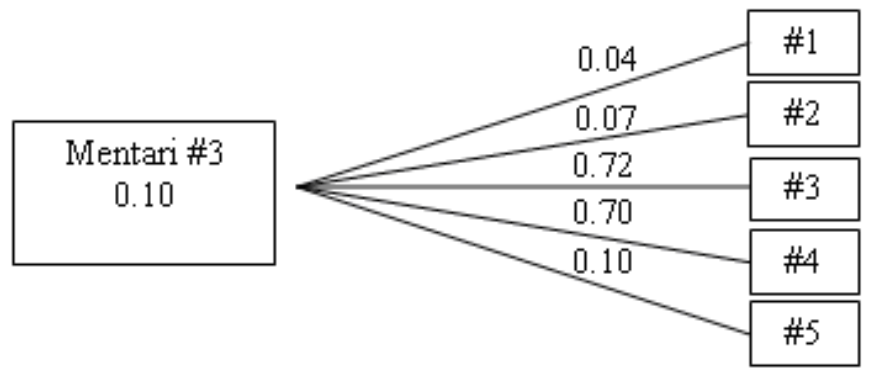

$0.004=0.10(0.04)$

$0.007=0.10(0.07)$

$0.072=0.10(0.72)$

$0.007=0.10(0.70)$

$0.01=0.10(0.10)$
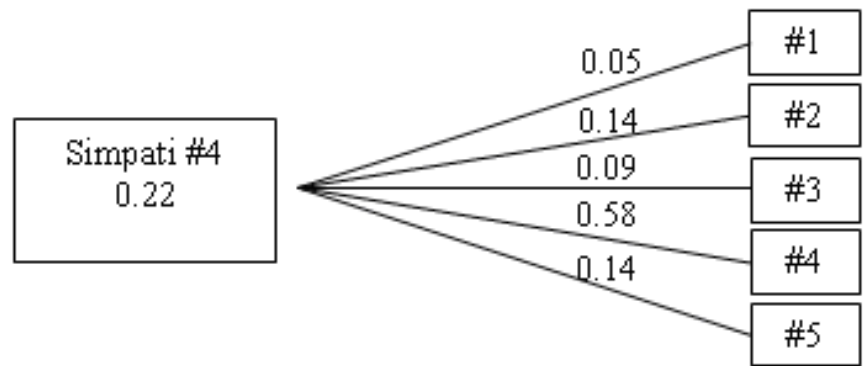

$0.011=0.22(0.05)$

$0.0308=0.22(0.14)$

$0.0198=0.22(0.09)$

$0.1276=0.22(0.58)$

$0.0308=0.22(0.14)$

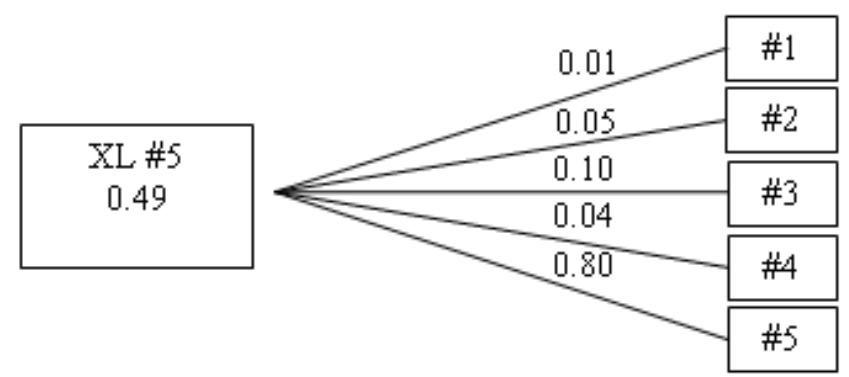

$0.0049=0.49(0.01)$

$0.0245=0.49(0.05)$

$0.049=0.49(0.10)$

$0.0196=0.49(0.04)$

$0.392=0.49(0.80)$

Sumber: Hasil Pengolahan Data, 2007

Gambar 2 Diagram Pohon Provider HP

Berdasarkan data yang telah dijelaskan sebelumnya, matriks transisi probabilitasnya akan menjadi seperti berikut ini.

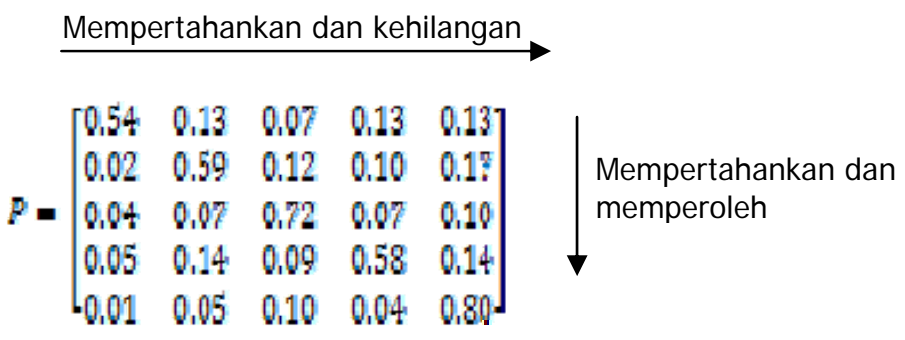

Provider AS mewakili state 1, Provider IM3 state 2, Provider Mentari state 3, Provider Simpati state 4, dan Provider XL state 5. Arti probabilitas tersebut dapat digambarkan seperti berikut. 


\section{Baris 1}

$0.54=\mathrm{P}_{11}=$ probabilitas pangsa pasar AS setelah sebelumnya merupakan pengguna AS

$0.13=\mathrm{P}_{12}=$ probabilitas pangsa pasar IM3 setelah sebelumnya merupakan pengguna AS

$0.07=\mathrm{P}_{13}=$ probabilitas pangsa pasar Mentari setelah sebelumnya merupakan pengguna AS

$0.13=\mathrm{P}_{14}=$ probabilitas pangsa pasar Simpati setelah sebelumnya merupakan pengguna AS

$0.13=\mathrm{P}_{15}=$ probabilitas pangsa pasar XL setelah sebelumnya merupakan pengguna AS

\section{Baris 2}

$0.02=\mathrm{P}_{21}=$ probabilitas pangsa pasar AS setelah sebelumnya merupakan pengguna IM3

$0.59=\mathrm{P}_{22}=$ probabilitas pangsa pasar IM3 setelah sebelumnya merupakan pengguna IM3

$0.12=\mathrm{P}_{23}=$ probabilitas pangsa pasar Mentari setelah sebelumnya merupakan pengguna IM3

$0.10=\mathrm{P}_{24}=$ probabilitas pangsa pasar Simpati setelah sebelumnya merupakan pengguna IM3

$0.17=\mathrm{P}_{25}=$ probabilitas pangsa pasar XL setelah sebelumnya merupakan pengguna IM3

\section{Baris 3}

$0.04=\mathrm{P}_{31}=$ probabilitas pangsa pasar AS setelah sebelumnya merupakan pengguna Mentari

$0.07=\mathrm{P}_{32}=$ probabilitas pangsa pasar IM3 setelah sebelumnya merupakan pengguna Mentari

$0.72=\mathrm{P}_{33}=$ probabilitas pangsa pasar Mentari sebelumnya merupakan pengguna Mentari

$0.07=\mathrm{P}_{34}=$ probabilitas pangsa pasar Simpati sebelumnya merupakan pengguna Mentari

$0.10=\mathrm{P}_{35}=$ probabilitas pangsa pasar XL sebelumnya merupakan pengguna Mentari

\section{Baris 4}

$0.05=\mathrm{P}_{41}=$ probabilitas pangsa pasar AS setelah sebelumnya merupakan pengguna Simpati

$0.14=\mathrm{P}_{42}=$ probabilitas pangsa pasar IM3 setelah sebelumnya merupakan pengguna Simpati

$0.09=\mathrm{P}_{43}=$ probabilitas pangsa pasar Mentari sebelumnya merupakan pengguna Simpati

$0.58=\mathrm{P}_{44}=$ probabilitas pangsa pasar Simpati sebelumnya merupakan pengguna Simpati

$0.14=\mathrm{P}_{45}=$ probabilitas pangsa pasar XL sebelumnya merupakan pengguna Simpati

\section{Baris 5}

$0.01=\mathrm{P}_{51}=$ probabilitas pangsa pasar AS setelah sebelumnya merupakan pengguna $\mathrm{XL}$

$0.05=\mathrm{P}_{52}=$ probabilitas pangsa pasar IM3 setelah sebelumnya merupakan pengguna XL

$0.10=\mathrm{P}_{53}=$ probabilitas pangsa pasar Mentari setelah sebelumnya merupakan pengguna $\mathrm{XL}$

$0.04=\mathrm{P}_{54}=$ probabilitas pangsa pasar Simpati setelah sebelumnya merupakan pengguna $\mathrm{XL}$

$0.80=\mathrm{P}_{55}=$ probabilitas pangsa pasar XL setelah sebelumnya merupakan pengguna XL 


\section{PENUTUP}

Simpulan yang diperolah berdasarkan penelitian adalah dapat diperoleh perkiraan pangsa pasar dari kelima operator GSM di Indonesia di masa datang diperkirakan AS akan menguasai $13.2 \%$ pasar, IM3 menguasai $19.6 \%$ pasar, Mentari menguasai $22 \%$ pasar, Simpati menguasai 18,4 \% pasar dan XL menguasai 26,8 \% pasar. Analisis menggunakan metode Rantai Markov hanya dapat dipakai untuk melihat perubahan/ perpindahan untuk jangka relatif pendek, kecuali apabila melihat hasil akhirnya perpindahannya tidak terlalu signifikan maka perlu dipertimbangkan untuk penggunaan jangka yang relatif panjang.

\section{DAFTAR PUSTAKA}

Abdurahman, Edi. "Konsep Dasar Markov Chain dan Kemungkinan Penerapannya," diakses pada tanggal 20 Juli 2007 dari http://www.litbang.deptan.go.id/wartaip/pdf-file/edi.pdf,

Darmawan, A. 1996. Dilema Paritas Program. Jakarta: Cakram.

Dimyati, T.T dan A. Dimyati. 1992. Operation Research Model-model Pengambilan Keputusan. Edisi 2. Bandung: Sinar Baru.

Heizer, Jay dan Barry Render. 2006. Manajemen Operasi. Edisi Ketujuh. Jakarta: Salemba Empat.

Isaacson, D.L. and R.W. Madsen. 1976. Markov Chains Theory and Aplications. New York: John Wiley and Sons.

Kotler, Phillip. 2002. Manajemen Pemasaran. Jakarta: Pearson Education Asia.

Subagyo, Pangestu, Marwan Asri, dan T. Hani Handoko. 1989. Dasar-Dasar Operations Research. Yogyakarta: BPFE. 